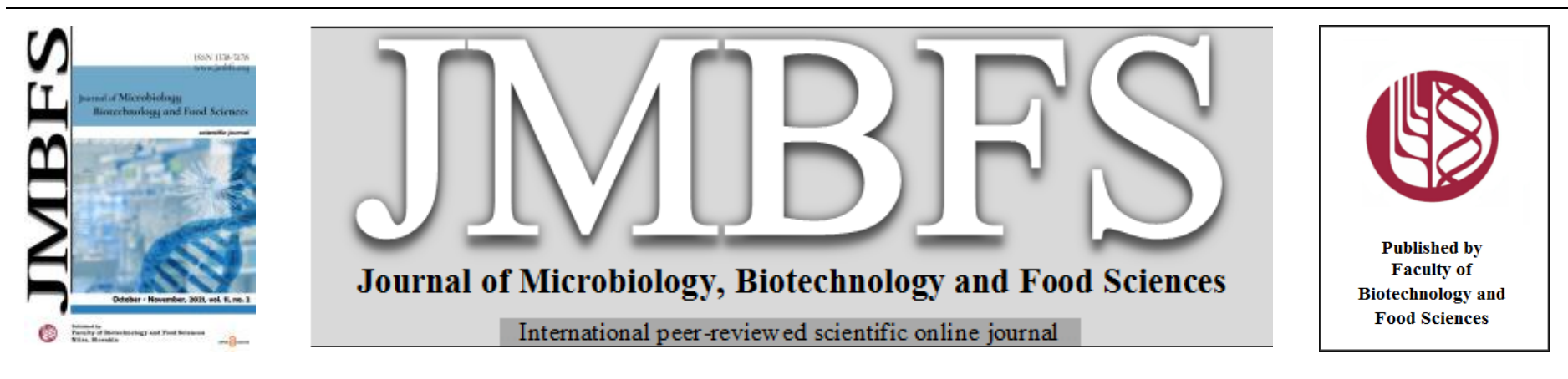

\title{
IMPACT OF CADMIUM TOXICITY ON LEAF AREA AND STOMATAL CHARACTERISTICS IN FABA BEAN
}

\author{
Beáta Piršelová ${ }^{*}$, Veronika Kubová ${ }^{1}$, Peter Boleček ${ }^{1}$, Alžbeta Hegedüsová ${ }^{2}$
}

\begin{abstract}
Address(es):
${ }^{1}$ Constantine the Philosopher University in Nitra, Faculty of Natural Sciences, Department of Botany and Genetics, Nábrežie mládeže 91,94974 Nitra, Slovakia.

${ }^{2}$ Slovak University of Agriculture in Nitra, Faculty of Horticulture and Landscape Engineering, Department of Vegetable Production, Tr. A. Hlinku 2, 94976 Nitra, Slovakia.
\end{abstract}

*Corresponding author: bpirselova@ukf.sk

https://doi.org/10.15414/jmbfs.3718

\section{ARTICLE INFO}

Received 16. 9. 2020

Revised 30. 4. 2021

Accepted 11. 5. 2021

Published 1. 10. 2021

Regular article

open $\partial_{\text {ACCESS }}$

\begin{abstract}
Although changes in stomatal response to elevated doses of cadmium has already been observed in several plants, few studies have focused on this phenomenon in more detail. The effects of different doses of cadmium $\mathrm{Cd}^{2+}$ (50 and $100 \mathrm{mg} \cdot \mathrm{kg}^{-1}$ soil) on leaf area and stomatal characteristics (number of stomata, number of epidermal cells, stomatal index and size of stomata) of faba bean (Vicia faba $\mathrm{L}$. cultivar Aštar) were studied after 15 days of heavy metal treatment. No visual changes on adaxial or abaxial side of leaves of the tested variety of faba bean were found. The leaf area was higher by $14.15 \%$ at lower and by $12.23 \%$ at the higher doses of Cd. The tested doses of $\mathrm{Cd}$ did not lead to a change in the number of stomata. The number of epidermal cells was increased on adaxial side by $4.98 \%$ at dose Cd50. Stomatal index was decreased due to the effect of higher dose of cadmium by $11.38 \%$ on adaxial side of leaves. In stomatal widths, decrease by $2.04 \%$ (adaxial side) and $2.26 \%$ (abaxial side) was observed at higher doses of Cd. In stomatal length decrease by $1.85 \%$ was observed at higher dose of $\mathrm{Cd}$ on adaxial and decrease by $3.89 \%(\mathrm{Cd} 50)$ and $4.63 \%(\mathrm{Cd} 100)$ on abaxial side of leaves respectively. The variations of response could be signals of tolerance or adaptive mechanisms of the leaves of tested bean cultivar under the used concentrations of cadmium.
\end{abstract}

Keywords: plant defense, faba bean, cadmium, stomata, leaf area

\section{INTRODUCTION}

Cadmium (Cd) does not have an essential function in any living organism; thus even a low concentration of this metal is toxic to organisms. Due to high accumulation potential of cadmium, the single links of the food chain get contaminated relatively fast (Demková et al., 2017). Agricultural crops show varied levels of sensitivity to the given metal; with majority of them accumulating $\mathrm{Cd}$ in roots (Vamerali et al., 2012, Wu 1990). In plants, exposure to $\mathrm{Cd}$ causes oxidative stress, inhibition of growth, nutritional imbalances, changes in the activity of many enzymes, reduction of a transpiration rate and water content (Barceló and Poschenrieder, 1988; Benavides et al., 2005; Kuklová et al., 2017). In addition, it causes stomatal closure due to entry of $\mathrm{Cd}$ into the guard cells in competition to $\mathrm{Ca}^{+2}$ (Perfus-Barbeoch et al., 2002). Decrease in stomatal density is also characteristic symptom of $\mathrm{Cd}$ stress resulting in lesser conductance to $\mathrm{CO}_{2}$ (Pietrini $\boldsymbol{e t}$ al., 2010) which consequently leads to inhibition of photosynthesis. However, it is accepted that the factors limiting photosynthesis have stomatal and non-stomatal nature (Vassilev and Yordanov, 1997). Reduced photosynthetic activity is often due to iron deficiency in cadmium treated leaves (Zhang et al., 2011). The changes in the stomatal density, size of stomata and epidermal cells as a response to environmental stress are important means of regulating the rate of absorption of risk elements by plants, while the stomatal index often remains unchanged (Gostin, 2009). Several authors suggest that leaves of resistant species show xeromorph characteristics, which most probably help plants adapt to the increased concentrations of heavy metals and gases (Kutschera-Mitter et al., 1982; Nikolaevkij, 1989). Many studies have attempted to clarify the mechanism of heavy metal toxicity in plants (Benavides et al., 2005; Procházková et al., 2014; Kohanová et al., 2018). However, the high variability in the response of different genotypes to ions of $\mathrm{Cd}$ often results in contradictory relations between toxicity and physiological processes occurring in plants (Vassilev and Yordanov, 1997). In addition, $\mathrm{Cd}$ can interfere in several ways on the parameters that affect this physiological processes in leaves (Poschenrieder and Barceló, 2004).

Although fabaceae are relatively sensitive to higher doses of metals (Inohue $\boldsymbol{e t}$ al., 1994), results of several studies suggest that plants such as Lupinus albus, Vicia faba and Trifolium repens show tolerance to cadmium and may be used in re-vegetation and phytostabilization of cadmium contaminated soils (Verma et al., 2006, Pichtel and Bradway, 2008; Bidar et al., 2009).

In the present article, the influence of different concentrations of cadmium ions (50 and $100 \mathrm{mg} \cdot \mathrm{kg}^{-1}$ soil) on leaf area, stomata size and frequency in faba bean cv. Aštar are presented.

\section{MATERIAL AND METHODS}

\section{Plant material and growth conditions}

Seeds of beans (Vicia faba cv. Aštar) were surface-sterilized with $5 \%$ sodium hypochloride for $5 \mathrm{~min}$ and planted in pots containing mix of soil (BORA, $\mathrm{pH} 6$; $\left.1,0 \% \mathrm{~N} ; 0,3 \% \mathrm{P}_{2} \mathrm{O}_{5} ; 0,4 \% \mathrm{~K}_{2} \mathrm{O}\right)$ and perlite (4:1). The plants were cultivated in a growth chamber at $20{ }^{\circ} \mathrm{C}, 12$ hours light/ 12 hours dark period (illumination of 400 lux), and relative humidity $60-70 \%$. Pots were watered daily to $60 \%$ water-holding capacity of the soil. When the first assimilating leaves were developed, plants were supplied with distilled water (control) or two $\mathrm{Cd}^{2+}$ ion solutions with concentrations of 50 and $100 \mathrm{mg} \cdot \mathrm{kg}^{-1}$ of soil (Cd50 and Cd100). Cadmium was added as $\mathrm{Cd}\left(\mathrm{NO}_{3}\right)_{2} \cdot 4 \mathrm{H}_{2} \mathrm{O}$ (Piršelová et al., 2016). On day 15 after application of metal solutions, the following characteristics were determined: leaf area, stomatal density, stomatal index, length and width of stomata in both adaxial (upper) and abaxial (lower) surface of leaves. Three replicates were used per treatment and 8 plants per pot were analyzed (altogether 24 plants).

\section{Number of stomata, size of stomata and stomatal index determination}

The number and size of stomata were assessed after 15 days of growth in contaminated soil on upper (adaxial) and lower (abaxial) sides of leaves using clear nail polish, tape, and a glass slide. Leaves of similar size and maturity were used. The stomatal samples were collected at conditions with a temperature of 25 ${ }^{\circ} \mathrm{C}$ during 9:30-11:00 am. In total 24 microscopic fields of each epidermis and variant of experiments were randomly selected and examined using the Zeiss Axioplan II optical microscope and then they were counted. The number of stomata was expressed per $\mathrm{mm}^{2}$ of leaf area. To determine stomatal length and width, 50 randomly chosen stomata on each leaf (variant of experiments) were measured at $400 \times$ magnification. Images were obtained using Sony DXCS500 
digital camera and analysed with AxioVision AC software (Zeiss, Germany). Stomatal density was defined as the number of stomata per square millimeter of leaf surface. Stomatal index (SI) was calculated using the equation of Salisbury (1927). It is defined as:

$$
\text { SI (\%) } \frac{\text { stomatal density }}{\text { stomatal density - epidermal cell density }} \times 100
$$

\section{Determination of leaf area}

Leaf area was determined gravimetrically.

\section{Measurements of cadmium content in leaves}

Dried plant material ( $0.5 \mathrm{~g}$ roots and shoots) was digested in the mixture of $5 \mathrm{~mL}$ water, $5 \mathrm{~mL}$ of concentrated $\mathrm{HNO}_{3}$ p.a. (Merck, Darmstadt, Germany), and 1.5 $\mathrm{mL}$ of $\mathrm{H}_{2} \mathrm{O}_{2}$ p.a. (Slavus, Bratislava) by using the microwave oven Mars Xpress (CEM Corporation, Matthews, USA). Decomposition temperature was $140{ }^{\circ} \mathrm{C}$, ramp time $15 \mathrm{~min}$, and hold time $13 \mathrm{~min}$. After digestion, the solution was diluted to $25 \mathrm{~mL}$ with deionised water and filtered through an acid-resistant cellulose filter (Whatman No. 42). Blank samples were prepared in a similar way. The cadmium was determined by electrothermal atomic absorption spectroscopy (AAS Perkin Elmer 1100B, Nor-walk, Connecticut, USA) (Dobroviczká et al. 2013, Piršelová et al., 2016).

\section{Statistical analysis}

Data were analyzed by one-way ANOVA or Kruskal-Wallis tests using XLSTAT software. Data are expressed as the means the replicates \pm standard deviation.

\section{RESULTS AND DISCUSSION}

\section{Plant growth}

Plants grown for 15 days in soil contaminated with cadmium did not show any visual symptoms of metal toxicity, such as chlorosis, necrotic lesions or wilting. Similar conclusions were presented in a study by Dobroviczká et al. (2013) with soybeans exposed to dose of $\mathrm{Cd}$ of $50 \mathrm{mg} \cdot \mathrm{kg}^{-1}$ soil. Changes in the evaluated parameters of shoots (fresh and dry weight of shoots, shoot length) were statistically insignificant compared to the control; a decrease in the content of root biomass was noted (Piršelová et al., 2016).

\section{Cadmium accumulation}

The rate of cadmium accumulation in the roots and shoots was proportional to the dose of cadmium applied (Table 1). The accumulation of $\mathrm{Cd}$ in the roots was more pronounced, the reduced transport of $\mathrm{Cd}$ to the shoots may contribute to the plant tolerance to higher doses of Cd. (Zornoza et al., 2002).

Table 1 Cadmium content in roots and shoots ( $\mu \mathrm{g} \cdot \mathrm{g}^{-1}$ dry weight).

\begin{tabular}{lcc}
\hline Variant of experiment & Root & Shoot \\
\hline Control & $0.50 \pm 0.01 \mathrm{Aa}$ & $0.10 \pm 0.03 \mathrm{Ab}$ \\
Cd50 & $62.26 \pm 9.60 \mathrm{Ba}$ & $13.73 \pm 3.27 \mathrm{Bb}$ \\
Cd100 & $86.40 \pm 0.99 \mathrm{Ba}$ & $16.53 \pm 4.37 \mathrm{Bb}$ \\
\hline
\end{tabular}

Legend: Different upper case letters within a column and different lower case letters within a row indicate results significant at $\mathrm{p}<0.05$ (Kruskal-Wallis test).

Since the level of translocation of $\mathrm{Cd}$ from the roots to the shoots proved to be low, we assume its translocation to the seeds to be also low. However, single varieties of faba bean can have different levels of accumulation of $\mathrm{Cd}$ in their tissues. The selection of plant genotypes with low cadmium accumulation using genetic markers can contribute to rapid identification of plants suitable for growing in soils with a certain metallic load (Socha et al., 2015; Vollmann et al., 2015).

\section{Number of stomata, size of stomata and stomatal index determination}

Changes in the size and number of stomata are a manifestation of the plants response to changes in the environment and are an important tool in regulating the absorption of pollutants by plants (Gostin, 2009). Compared with guard cell length, stomatal density is relatively plastic and potentially adaptive to environmental changes (Sekiya and Yano, 2008). Leaves treated with Cd50 and Cd100 showed decreased number of stomata by $5.72 \%$ and $2.9 \%$ respectively on the adaxial side and by 5.13 and $1.0 \%$ respectively on the abaxial side; these changes were insignificant (Figure 1).

The number of epidermal cells was increased significantly on adaxial surfaces (by $4.98 \%$ ) and decreased, but not significantly (by $13.37 \%$ ) on abaxial surfaces at doses $\mathrm{Cd} 50$ and $\mathrm{Cd} 100$ respectively (Figure 1). Stomatal index decreased significantly on adaxial side of leaves (Figure 2).
Results of the studies aimed at observing the number of stomata and epidermal cells affected by heavy metals are contradictory. Several authors (Kastori et al., 1992; Chwil, 2005; Shi and Caia, 2009) mentioned that number of stomata of epidermis increased with increased concentration of heavy metals. In contrast, however, cadmium decreased number of stomata on abaxial side of leaves of sorghum (Sorghum bicolor) Kasim (2006). Decrease in the number of stomata caused by the effect of cadmium was observed also on the leaves of oilseed rape by Baryla et al. (2001). Decrease in the number of epidermal cells due to meta contamination was also recorded by Makovníková (2001) and Gostin (2009). The given contradictions can be caused also by the differing reactions of the single parts of leaves to the different types of stress (Saidulu et al., 2014) Positive and negative correlations were also noticed among the metal concentrations and the number of stomata on the both sides of the leaves (Chwil, 2005).

Stomatal index was decreased due to the effect of both doses of cadmium by 9.83 $\%$ and $11.38 \%$ (adaxial side) and by $3.07 \%$ and $1.00 \%$ (abaxial side), however only decrease on adaxial side of leaf at higher dose of cadmium was statistically significant (Figure 3). These changes may be the result of increased oxidative stress in the leaves of the test variety of beans at a dose of cadmium $100 \mathrm{mg} . \mathrm{kg}^{-1}$ soil (Piršelová et al., 2016).
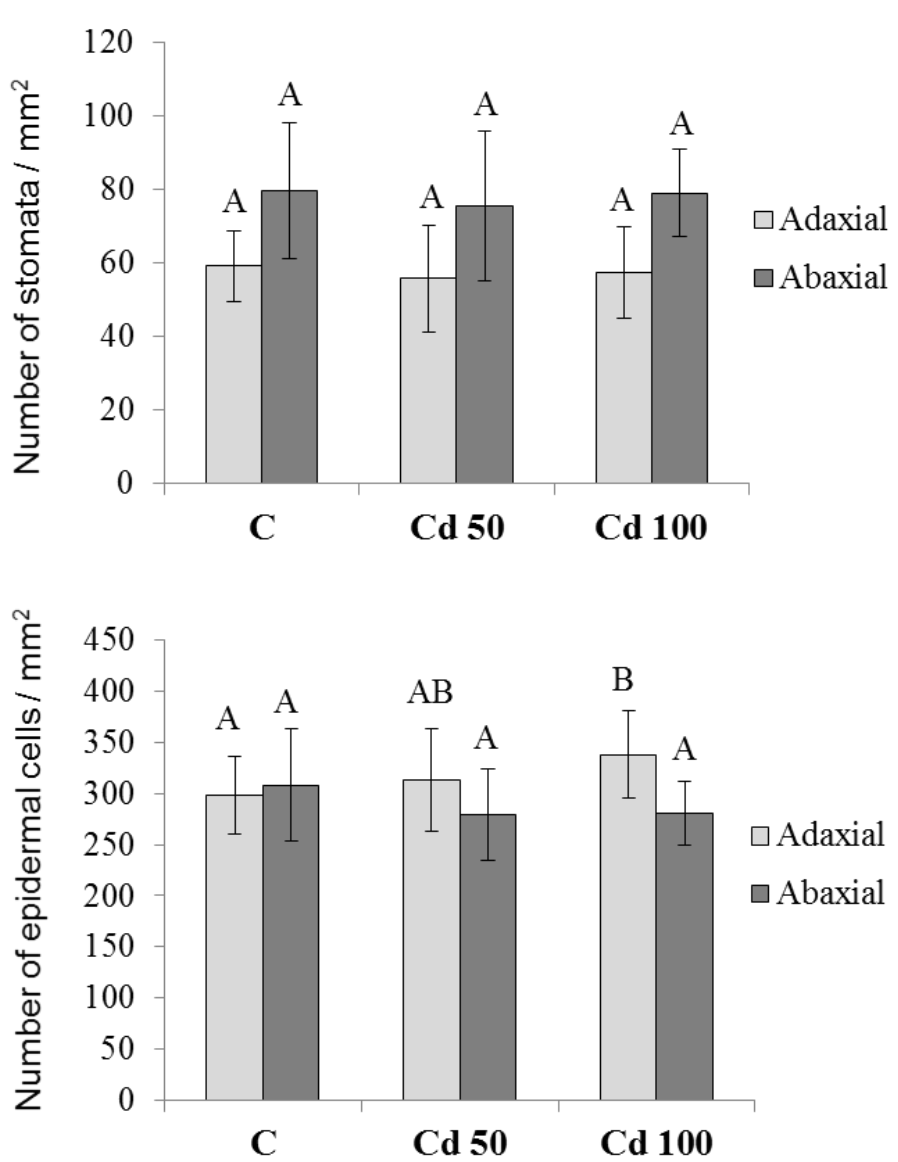

Cadmium dose (mg.kg-1 of soil)

Figure 1 Number of stomata and epidermal cells determined for adaxial and abaxial sides of leaves exposed to ions of $\mathrm{Cd}$ in concentrations of 0 (control $-\mathrm{C}$ ), 50 or $100 \mathrm{mg} \cdot \mathrm{kg}^{-1}$ of soil (Cd50 and Cd100). Bars indicate \pm standard deviation of mean values $(\mathrm{n}=25)$. Columns with the same letter are not significantly different $(\mathrm{p}<0.05$, Kruskal-Wallis test). 


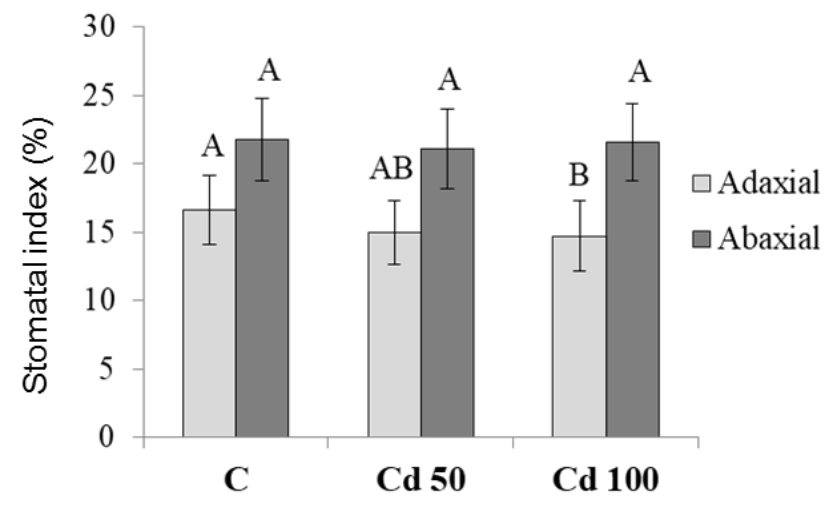

Cadmium dose (mg. $\mathrm{kg}^{-1}$ of soil)

Figure 2 Stomatal indexes determined for adaxial and abaxial sides of leaves exposed to ions of $\mathrm{Cd}$ in concentrations of 0 (control - C), 50 or $100 \mathrm{mg} \cdot \mathrm{kg}^{-1}$ of soil $(\mathrm{Cd} 50$ and $\mathrm{Cd} 100)$. Bars indicate \pm standard deviation of mean values $(\mathrm{n}=$ $25)$. Columns with the same letter are not significantly different $(\mathrm{p}<0.05$, Kruskal-Wallis test).

Similar findings were also reached by Verma et al. (2006) in their experiments with cadmium who observed decrease in stomatal index in upper epidermis in Ipomea pes-tigridis. In contrast, however, an increase in stomatal index was noted on the abaxial side of Trifolium montanum and T. repens and no significant changes were noted on the abaxial side of $T$. pratense and Lotus corniculatus (Gostin, 2009).

In stomatal widths, statistically significant decrease by $2.04 \%$ (adaxial side) and $2.26 \%$ (abaxial side) was observed at higher doses of Cd (Figure 3).
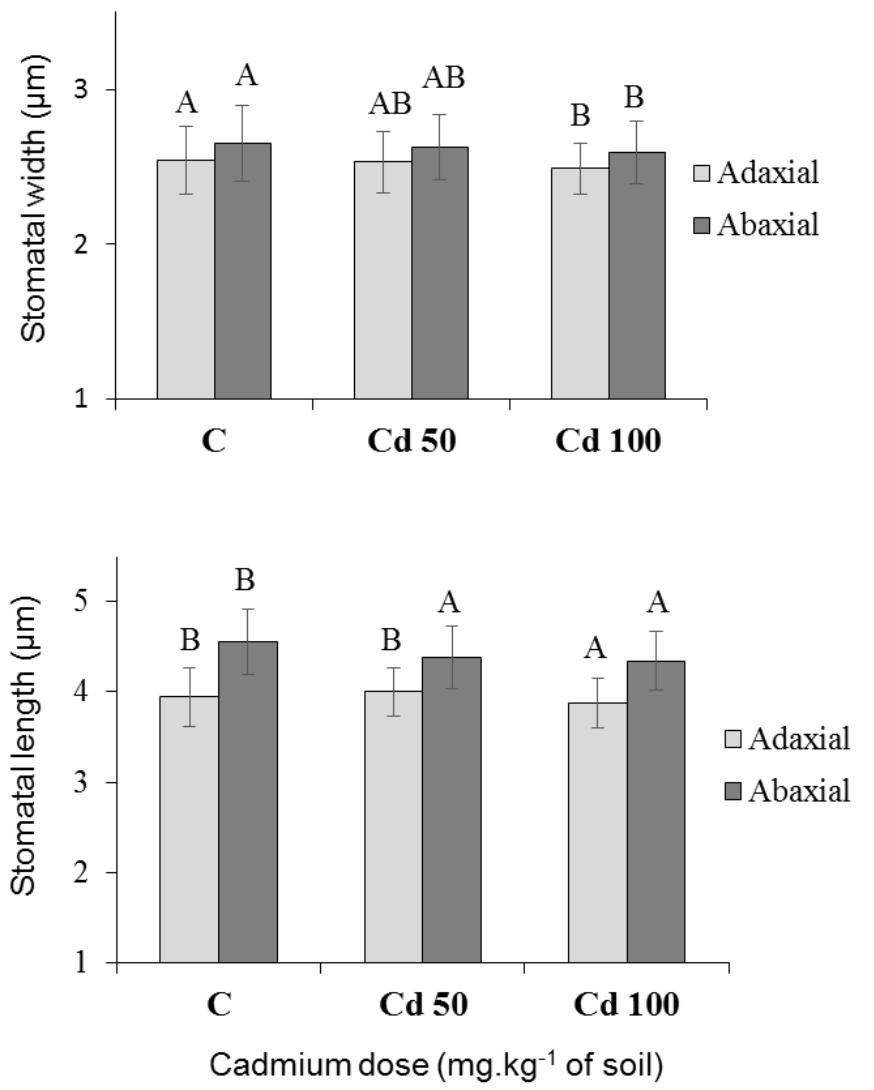

Figure 3 Changes in length and width of stomata on adaxial and abaxial surface of leaves exposed to ions of $\mathrm{Cd}$ in concentrations of 0 (control - C), 50 or 100 mg. $\mathrm{kg}^{-1}$ of soil. Bars indicate \pm standard deviation of mean values $(\mathrm{n}=190)$. Columns with the same letter are not significantly different $(\mathrm{p}<0.05$, KruskalWallis test).

In stomatal length decrease by $1.85 \%$ was observed at higher dose of $\mathrm{Cd}$ on adaxial surface and decrease by $3.89 \%(\mathrm{Cd} 50)$ and $4.63 \%(\mathrm{Cd} 100)$ on abaxial surfaces respectively (Figure 3 ).
Application of the lower doses of $\mathrm{Cd}$ resulted in less pronounced changes, while these mostly reflect the negative impact of $\mathrm{Cd}$ on the size of stomata, especially the length on abaxial leaf side (Figure 3). Shortening the stomata on the adaxia side of leaves of Arachis hypogaea $\mathrm{L}$. after application of cadmium is reported also by Shi and Caia (2009) in their study.

Several other authors reported decreasing size of stomata with increasing concentrations of $\mathrm{Cd}$ ions applied in the form of $\mathrm{CdCl}_{2}$ solution (Gostin, 2009; Pereira et al., 2016). Increase in stomatal density, the number of stomata and reduction in the size of guard cells per unit area represent a self-defense system, which is developed in plants under stress conditions and helps them survive in the contaminated environment (Azmat et al., 2009).

\section{Effect of cadmium on leaf area}

The change in leaf area due to cadmium is a common phenomenon associated with a reduction in the transpiration rate (Lai et al., 2015). In our experiments the leaf area was higher by $14.15 \%$ at lower and by $12.23 \%$ at the higher doses of cadmium (Figure 4).

The stimulatory effect of low doses of chemicals on plant growth is referred to as hormesis (Calabrese, 2009). Although the knowledge about mechanisms of hormesis is growing, the phenomenon is not sufficiently explained so far. Stimulation tends to increase plant defense and is mainly due to induction of synthesis of defense molecules (stress proteins), secondary metabolites, alteration of antioxidant enzyme activity and reduction of oxidative stress by inhibiting lipid peroxidation of membranes (Allender et al., 1997). In the tested cultivar enhanced accumulation of PR proteins (chitinases) was recorded in roots treated of cadmium, lead and arsenic (Békésiová et al., 2008).

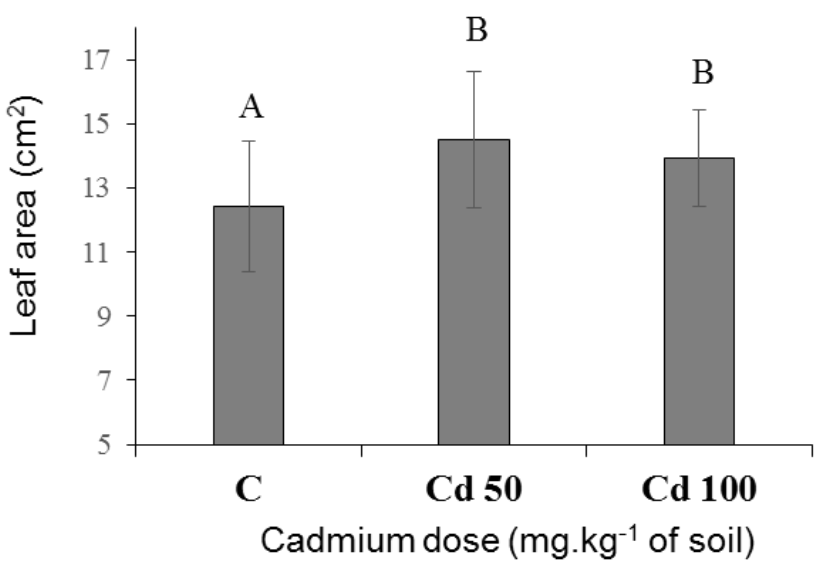

Figure 4 Effect of cadmium (50 or $100 \mathrm{mg} \cdot \mathrm{kg}^{-1}$ of soil) on leaf area. Column with the same letter are not significantly different $(\mathrm{p}<0.05$, Kruskal-Wallis test) $\mathrm{C}$ - control.

\section{CONCLUSION}

We observed no visual symptoms of toxicity on the leaves of the tested variety of faba bean caused by the test doses of cadmium. The leaf area was higher by $14.15 \%$ at lower and by $12,23 \%$ at the higher doses of cadmium. We recorded no statistically significant changes in the monitored parameters of stomata caused by the lower dose of cadmium (Cd50) except of the length of stomata on the bottom side of leaves. Higher dose $(\mathrm{Cd} 100)$ caused decrease in the size of stomata on both sides of leaves and increase of the number of epidermal cells on adaxial side at the unchanged number of stomata, which lead to a decrease of the stomatal index. The variations of response could be signals of tolerance or adaptive mechanisms of the leaves under the determined concentrations. Deeper anatomic and physiological studies can contribute to the explanation of the role of cell epidermis of faba bean in its adaptation to ions of cadmium.

Acknowledgments: This work was supported by projects APVV-18-0154 and VEGA $1 / 0073 / 20$

\section{REFERENCES}

Allender, W. J., Cresswell, G. C., Kaldor, J. \& Kennedy, I. R. (1997). Effect of lithium and lanthium on herbicide induced hormesis in hydrophonically-grown cotton and corn. Journal of Plant Nutrition, 20, 81-95. https://doi.org/10.1080/01904169709365235

Azmat, R., Haider, S., Nasreen, H., Aziz, F. \& Riaz, M. (2009). A viable alternative mechanism in adapting the plants to heavy metal environment. Pakistan Journal of Botany, 41(6), 2729-2738. 
Barceló, J. \& Poschenrieder, C. (1990). Plant water relations as affected by heavy metal stress: a review. Journal of Plant Nutrition, 13(1), 1-37. https://doi.org/10.1080/01904169009364057

Baryla, A., Carrier, P., Franck, F., Coulomb, C., Sahut, C. \& Havaux, M. (2001) Leaf chlorosis in oilseed rape plants (Brassica napus) grown on cadmiumpolluted soil: causes and consequences for photosynthesis and growth. Planta, 212, 696-709.

https://doi.org/10.1007/s004250000439

Békésiová, B., Hraška, Š., Libantová, J., Moravčíková, J. \& Matušíková, I (2008). Heavy-metal stress induced accumulation of chitinase isoforms in plants. Molecular Biology Reports, 35, 579-588.

https://doi.org/10.1007/s11033-007-9127-x

Benavides, M. P., Gallego, S. M., \& Tomaro, M. L. (2005). Cadmium toxicity in plants. Brazilian Journal of Plant Physiology, 17(1), 21-34 http://dx.doi.org/10.1590/S1677-04202005000100003

Calabrese, E. J. \& Blain, R. B. 2009. Hormesis and plant biology. Environmental Pollution, 157, 42-48. https://doi.org/10.1016/j.envpol.2008.07.028

Carpena, R. O. (2006). Use of white lupine plant for phytostabilization of $\mathrm{Cd}$ and as polluted acid soil. Water, Air, and Soil Pollution, 177(1-4), 349-365. https://doi.org/10.1007/s11270-006-9178-y

Bidar, G., Pruvot, C., Garcon, G., Verdin, A., Shirali, P. \& Douay, F. (2009). Seasonal and annual variations of metal uptake, bioaccumulation and toxicity in Trifolium repens and Lolium perenne growing in a heavy metal contaminated field. Environmental Science and Pollution Research International, 16, 42-53. https://doi.org/10.1007/s11356-008-0021-4.

Demková, L., Árvay, J., Bobulská, L., Tomáš, J., Stanovič, R., Lošák, T., Harangozo, L., Vollmannová, A., Bystrická, J., Musilová, J. \& Jobbágy, J. (2017). Accumulation and environmental risk assessment of heavy metals in soil and plants of four different ecosystems in a former polymetallic ores mining and smelting area (Slovakia). Journal of Environmental Science and Health. Part A: Toxic Hazardous Substances and Environmental Engineering, 52, 479490. https://doi.org/10.1080/10934529.2016.1274169

Dobroviczká, T., Piršelová, B., Mészáros, P., Blehová, A., Libantová, J. Moravčíková, J. \& Matušíková, I. (2013). Effects of cadmium and arsenic ions on content of photosynthetic pigments in the leaves of Glycine max (L.) Merrill. Pakistan Journal of Botany, 45, 105-110.

Gostin, I. N. (2009). Air pollution effects on the leaf structure of some Fabaceae species. Notulae Botanicae Horti Agrobotanici Cluj-Napoca, 37, 57-63.

Chwil, M. (2005). The influence of lead on structure of Cucumis sativus L. leaves. Folia Horticulturae, 17(2), 11-22.

Inouhe, M., Ninomiya, S., Tohoyama, H., Joho, M. \& Murayama, T. (1994) Different characteristics of roots in the cadmium-tolerance and Cd-binding complex formation between mono- and dicotyledonous plants. Journal of Plant Research, 107, 201-207.

Kasim, W. A. (2006). Changes induced by copper and cadmium in the anatomy and grain yield of Sorghum bicolor (L.) Moench. International Journal Agriculture Biology, 8, 123-128.

Kastori, R., Petrović, M. \& Petrović, N. (1992). Effects of excess lead, cadmium, copper and zinc on water relations in sunflower. Journal of Plant Nutrition, 15 1992, 2427-2439. https://doi.org/10.1080/01904169209364485

Kohanová, J., Martinka, M., Vaculík, M., White, P. J., Hauser, M. T. \& Lux, A (2018). Root hair abundance impacts cadmium accumulation in Arabidopsis thaliana shoots. Annals of Botany, 122, 903-914 https://doi.org/10.1093/aob/mcx220

Kuklová, M., Hniličková, H., Hnilička, F., Pivková, I. \& Kukla, J. (2017). Toxic elements and energy accumulation in topsoil and plants of spruce ecosystems. Plant Soil and Environment, 63(9), 402-408. http://doi.org/10.17221/364/2017PSE

Kutschera-Mitter, L., Lichtenegger, E. \& Sobotik, M. (1982). Vegetationswandel und Schadgasbelastung auf Grun- und Ackerland. In: Halbwachs, G. (ed), Das Immisionsokologishe Projekt Arnoldstein. Sonderh. 39, 1982, 121-168.

Lai, H. Y. (2015). Effects of leaf area and transpiration rate on accumulation and compartmentalization of cadmium in Impatiens walleriana. Water, Air, and Soil Pollution, 226, 2246. http://dx.doi.org/10.1007/s11270-014-2246-9

Makovníková, J. (2001). Distribution of $\mathrm{Cd}$ and $\mathrm{Pb}$ in main soil types of Slovakia. Agriculture, 47, 903-911.

Nikolaevskij, V. S. (1989). Ecologo-Morphological basis of gas resistance of plants. Moscovsk. Inst. Forest. Publ., Moscow (in Russian)

Pereira, M. P., Correa, F. F., Castro, E. M., Ribeiro, V. E., \& Pereira, F. J. (2016). Cadmium tolerance in Schinus molle trees is modulated by enhanced leaf anatomy and photosynthesis. Trees, 30, 807-814. https://doi.org/10.1007/s00468-015-1322-0

Perfus-Barbeoch, L., Leonhardt, N., Vavaseur, A. \& Forestier, C. (2002). Heavy metal toxicity: cadmium permeates through calcium channels and disturbs the plant water status. The Plant Journal, 32(4), 539-548. https://doi.org/10.1046/j.1365-313X.2002.01442.x.

Pietrini, F., Zacchini, M., Iori, V., Pietrosanti, L., Ferretti, M. \& Massacci, A. (2010). Spatial distribution of cadmium in leaves and on photosynthesis: examples of different strategies in willow and poplar clones. Plant Biology, $12(2), 355-363$ https://doi.org/10.1111/j.1438-8677.2009.00258.x

Pichtel, J. \& Bradway, D. J. (2008). Conventional cro-ps and organic amendments for $\mathrm{Pb}, \mathrm{Cd}$ and $\mathrm{Zn}$ treat-ment at a severely contaminated site. $\begin{array}{lll}\text { Bioresourse Technology, } & \text { 99(5), } & \text { 1242-1251. }\end{array}$ https://doi.org/10.1016/j.biortech.2007.02.042

Piršelová, B., Kuna, R., Lukáč, P. \& Havrlentová, M. (2016). Effect of cadmium on growth, photosynthesis pigments, iron and cadmium accumulation of faba bean (Vicia faba cv. Aštar), Agriculture, 62(2), 72-79. https://doi.org/10.1515/agri-2016-0008

Poschenrieder C. \& Barceló J. (2004). Water relations in heavy metal stressed plants. In: Prasad M.N.V. (ed.): Heavy Metals Stress in Plants: From Biomolecules to Ecosystems. 2nd Edition. Springer Verlag, Berlin, 249-270. http://dx.doi.org/10.1007/978-3-662-07743-6_9

Procházková, D., Haisel, D., Pavlíková, D., Száková, J. \& Wilhelmová, N. (2014). The impact of increased soil risk elements on carotenoid contents Central European Journal of Biology, 9(7), 678-685. https://doi.org/10.2478/s11535-014-0304-3

Saidulu, C. H., Venkateshwar, C., Gangadhar R. S. \& Ramkrishna, N. (2014) Morphological studies of medicinal plant of Withania somnifera (L.) Dunal grown in heavy metal treated (contaminated) soil. Journal of Pharmacognosy and Phytochemistry, 3(1), 37-42.

Sekiya, N. \& Yano, K. (2008). Stomatal density of cowpea correlates with carbon isotope discrimination in different phosphorus, water and $\mathrm{CO}_{2}$ environments New Phytologist, $\quad 179, \quad 799-807$. https://doi.org/10.1111/j.14698137.2008.02518.x.

Salisbury, E. J. (1927). On the causes and ecological significance of stomatal frequency, with special reference to the woodland flora. Philosophical Transactions of the Royal Society of London B, 216, 1-65. https://doi.org/10.1098/rstb.1928.0001

Shi, G. \& Caia, Q. (2009). Leaf plasticity in peanut (Arachis hypogaea L.) in response to heavy metal stress. Environmental and Experimental Botany, 67 112-117. https://doi.org/10.1016/j.envexpbot.2009.02.009

Socha, P., Bernstein, N., Rybanský, L., Mészáros, P., Gálusová, T., Spieß, N., Libantová, J., Moravčíková, J. \& Matušíková, I. (2015). Cd accumulation potential as a marker for heavy metal tolerance in soybean. Israel Journal of Plant Sciences, 62(3), 160-166. https://doi.org/10.1080/07929978.2015.1042307 Vamerali, T., Marchiol, L., Bandiera, M., Fellet, G., Dickinson, N. M., Lucchini, P., Mosca, G. \& Zerbi, G. (2012). Advances in agronomic management of phytoremediation: Methods and results from a 10-year study of metal polluted soils. Italian Journal of Agronomy, 7(4), 323-330. https://doi.org/10.4081/ija.2012.e42

Vassilev, A. \& Yordanov, I. (1997). Reductive analysis of factors limiting growth of cadmium treated plants: a review. Bulgarian Journal of Plant Physiology, 23, 114-133.

Verma, R. B., Mahmooduzzafar, Siddiqui, T. O. \& Iqbal, M. (2006). Foliar response of Ipomea pes-tigridis L. to coal-smoke pollution. Turkish Journal of Botany, 30(5), 413-417.

Vollmann, J., Lošák, T. , Pachner, M., Watanabe, D., Musilová, L. \& Hlušek, J. (2015). Soybean cadmium concentration: validation of a QTL affecting seed cadmium accumulation for improved food safety. Euphytica, 203, 177-184 https://doi.org/10.1007/s10681-014-1297-8

Wu, L. (1990). Colonisation and establishment of plants in contaminated sites. In Shaw, A. J. (Ed) Heavy Metal Tolerance in Plants: Evolutionary Aspects. CRC Press: Boca Raton, 269-284

Zhang, X. W., Zhang, M., Wang, Q. H., Qiu, X. K., Hu, G. Q. \& Dong, Y. J. (2011). Effect of exogenous nitric oxide on physiological characteristic of peanut under iron-deficient stress. Journal of Plant Nutrition and Fertilization, 17, 665 673

https://doi.org/10.1080/00103624.2013.867058

Zornoza, P., Vázquez, S., Esteban, E., Fernández-Pascual, M. \& Carpena, R (2002). Cadmium-stress in nodulated white lupine: Strategies to avoid toxicity. Plant Physiology and Biochemistry, 40, 1003-1009. https://doi.org/10.1016/S0981-9428(02)01464-X 